\title{
Dental Restoration
}

National Cancer Institute

\section{Source}

National Cancer Institute. Dental Restoration. NCI Thesaurus. Code C60718.

Replacement or reconstruction of a lost tooth structure. 